\title{
Acme, Pathosis, Furuncle: the Periapical Granuloma
}

\author{
Anubha Bajaj* \\ Consultant Histopathologist at A.B. Diagnostics, New Delhi
}

*Corresponding author: Anubha Bajaj, consultant Histopathologist at A.B. Diagnostics, A-1 Ring Road Rajouri Garden, New Delhi 110027, India, Tel: 00911141446785 / 00911125117399 ; E-mail: anubha.bajaj@gmail.com

\section{Introduction}

Periapical granulomas, periapical cyst and periapical abscess are enumerated as the bourgeois periapical lesions ${ }^{[1,2]}$. Periapical granuloma is a chronic inflammation located at the apex of a non vital tooth. It comprises of granulation and scar tissue permeated by diverse inflammatory cells (lymphocytes, plasma cells, macrophages, mast cells). The entity incorporates a granulomatous inflammation with preponderant macrophages (histiocytes) and multinucleated giant cells. Acute flare of a periapical granuloma induces an exuberant neutrophilic reaction besides the granulation tissue with chronic inflammation ${ }^{[3-6]}$. Aggravation of the periapical granuloma is clinically and on histology labelled as acute apical periodontitis ${ }^{[3]}$. A dormant periapical abscess may evolve into a periapical granuloma ${ }^{[7]}$.Thus periapical granuloma requires evaluation, categorization and histological correlation, to anticipate if the observed periapical lesion maybe agranuloma and a ramification of pulp necrosis ${ }^{[8]}$. Periapical granuloma may be redefined on histology.

\section{Schema}

Clinically apparent or suspicious periapical lesions containing non vital teeth and specific preoperative radiology are analyzed. Routine histopathology of an extracted single tooth is performed. Residual periapical tissue is curetted from the extraction crater for histopathology to diagnose a periapical granuloma. Additional information elicited is the patient age, sex, clinical diagnosis, subtypes on histology (as per the inflammatory exudates) and the evolution of the lesion. The disorder occurs primarily between third and fourth decades of life with a Male to Female preponderance of 2:1. Pain and swelling of the jaw is delineated with deterioration of the pulp as evaluated by the pulp test. A well demarcated radiolucent zone evolves from the mesial to the distal root as visualized on a periapical radiograph. The residual vital teeth express a typical reaction / sensitivity.

\section{Histopathology}

Chronic inflammation, hyperaemia and oedema of the periodontal ligament are observed. Contraction of the abutting adjacent bone accompanies the vascular amplification and localized inflammation. Bone absorption occurs besides the fibroblastic and endothelial proliferation which constitutes the fibrils with tiny vascular conduits. Nascent capillaries are lined with plump endothelium. The homogenous lesion is predominantly comprised of macrophages, lymphocytes and plasma cells. The inflamed periodontal ligament abuts the epithelium. The anastomosing cords and sheets of metaplastic stratified squamous epithelium emerge from the apical foramina. The classic early, intermediate and late histological subtypes coincide with the inconstant clinical depictions of the peri - apical granuloma. Acute apical peri-odontitis may combine with the periapical granuloma to elucidate foamy macrophages and lymphocytes.

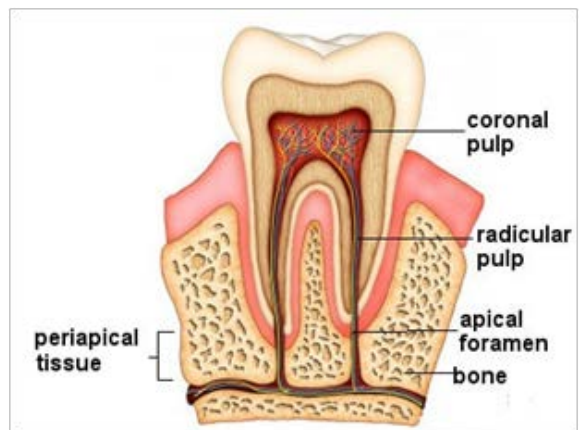

Figure 1: The site of inflammation.

Multiple histological versions of the peri radicular lesions are elicited such as the peri - apical abscess, the peri-apical granuloma, the peri - apical cyst, chronic osteomyelitis, pulse granuloma, fibro epithelial hyperplasia, peri - apical cemental dysplasia, ossifying fibroma, odontogenic fibroma, central giant cell granuloma, granular cell tumour, adeno - lymphoma, intraosseous nevi, squamous cell carcinoma, Burkitt's Lymphoma , Non Hodgkin's Lymphoma etc ${ }^{[15]}$.

\section{Colloquy}

Peri - apical radiolucent conditions are frequent. Apical granuloma is a natural progression of chronic apical peri - odon-
Received date: May 52018
Accepted date: May 122018
Publish date: May 172018

Citation: Anubha, B. Acme, Pathosis, Furuncle: the Periapical Granuloma. (2018) J Gastrointest Disord Liver Func 4(1): 11- 13.

Copy Rights: (C) 2018 Anubha, B. This is an Open access article distributed under the terms of Creative Commons Attribution 4.0 International License. 
titis. One fifth of the peri - apical conditions are inflammatory granulomas, predominantly affecting adult males ${ }^{[1]}$. However, the therapeutic intervention of the peri - apical granulomas in the adult's males is deferred until the lesion undergoes an acute flare. Acute apical periodontitis correlates clinically with the histopathology of periapical granuloma, comprising chiefly of foamy macrophages and lymphocytes. Nevertheless, Acute flares of periapical granuloma may coexist with marked neutrophilic infiltration and chronic inflammatory granulation tissue ${ }^{[3-6]}$. However acute peri - apical periodontitis frequently presents as an acute flare of the periapical granuloma, while the periradicular abscess may occasionally demonstrate an acute flare on histopathology. Periapical granulomas are categorized on histology into EARLY, INTERMEDIATE and LATE Phase due to the inflammatory exudates (LMN: Lymphocytes, Macrophages and Neutrophils in varying proportions and blends). The majority of the periapical granulomas are early stage lesions. The early stage delineates oedema and intense inflammation with permeation of foamy macrophages with pale cytoplasm the exudation of neutrophils, lymphocytes and other chronic inflammatory cells is negligible. Acute phase reaction with hyperaemia, oedema and chronic inflammatory (principally macrophage) impregnation in the periodontal ligament is comparable to the early stage ${ }^{[9]}$. The intermediate stage is defined by chronic inflammatory cells such as lymphocytes and plasma cells enmeshed with numerous blood vessels. It may resemble the chronic pattern of peri - apical granuloma ${ }^{[5,6]}$ on account of the enhanced vascular proliferation and the absorption of the apex of dental root with the abutting bone ${ }^{[9]}$. The late or the healing stage exemplifies minimal chronic inflammation, prominent blood vessels, plump fibroblasts, haemosiderin granules and fibrous connective tissue stroma $^{[3]}$. This isanalogous to a category of periapical granuloma which elucidates fibroblastic proliferation, plump endothelium, the conformation of tiny vascular channels, abundant frail \& fibrillar connective tissue and an intensetransudation of chronic inflammatory cells such asmacrophages, lymphocytes and plasma cells ${ }^{[10]}$. Peri - apical granuloma is also enumerated into the IMMUNE and NON IMMUNE granuloma ${ }^{[9,11,12]}$. The immune granuloma has a dense infiltration of chronic inflammatory cells chiefly lymphocytes and plasma cells. The non immune granuloma incorporates chiefly macrophages and giant cells with scant plasma cells. In the early or acute stage of the lesion, macrophages are the immune cells that "expunge the efflux" and act as "antigen presenting cells" to other immune cells.

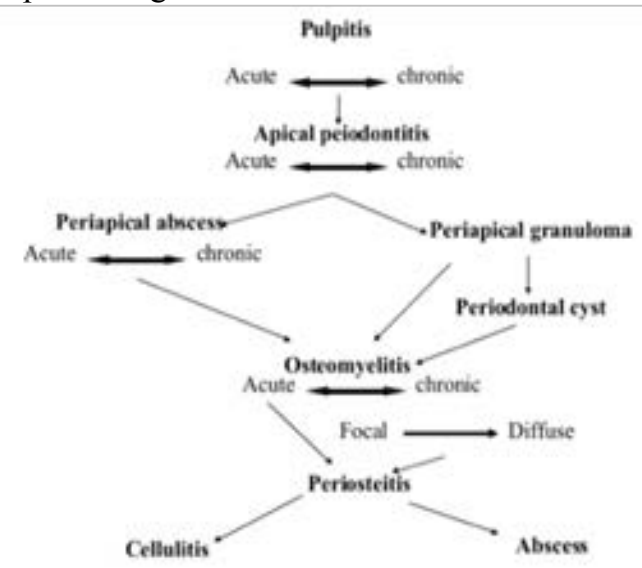

Figure 2 Pathogenesis of Periapical Inflammation

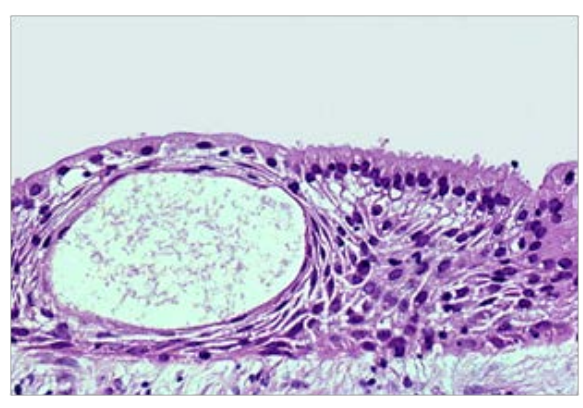

Figure 3: Periapical Periodontitis.

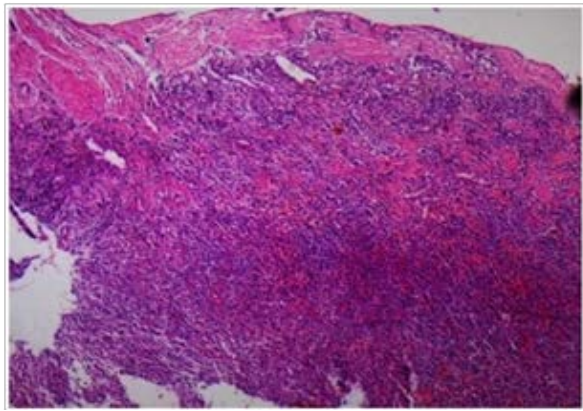

Figure 4: Periapical granuloma with intense inflammation.

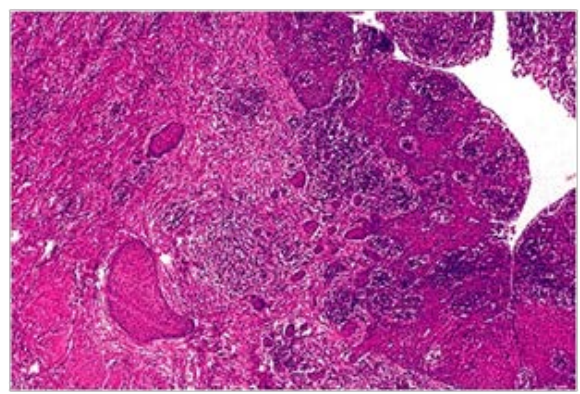

Figure 5: Prominent rests of malassez- periapical inflammation.

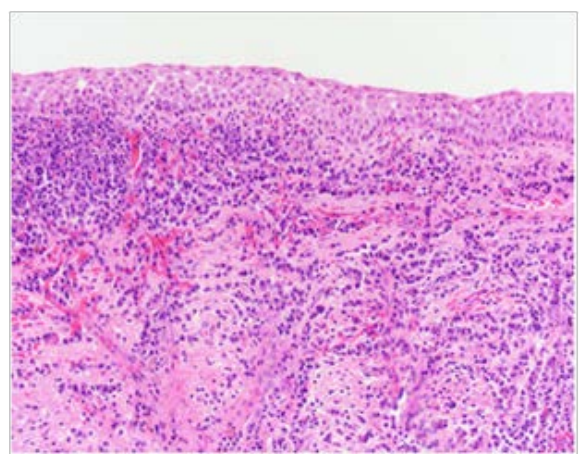

Figure 6: Periapical cyst with a squamous lining and an acute with chronic inflammation.

\section{Corollaries}

Periapical granuloma is a infrequent disorder ${ }^{[1,2]}$. Acute flare of the lesion elucidates an intense neutrophilic exudate. Preponderant foamy macrophages and lymphocytes visualized during the acute phase aids in the differentiation of apical periodontitis $^{[3,6,13]}$. The effluvium of the inflammatory cells designates the peri - apical granulomas into early, intermediate and late (healing) stages. Periapical granuloma (dental granuloma, chronic periapical periodontitis) may expose a defunct, tender tooth displaying minimal symptoms. A simmering infection adjacent to the root tip is consequent to an incompetent and deficient expurgation $^{[1-3]}$. Pulpitis or acute peri - apical periodontitis 
frequently terminates into a periapical granuloma.Pulp infections generally extend peri - apically.Adjunctive root canal or an aligned aperture on the lateral tooth surface is an established anatomic deviation which abets the furtherance of the inflammation. A lateral granuloma or an analogous inflammatory condition ensues ${ }^{[4,5]}$. Routine radiography helps elicit the radiolucent condition with the preponderant peri - apical granulomas.

\section{Pondered Therapies}

Extraction of the affected tooth or root canal treatment. With or without apicoectomy for specific case scenarios may be pertinent. Partially treated peri - apical granulomas may eventuate into an apical periodontal cyst secondary to the proliferation of localized epithelial cell rests. Endodontic retreatment may be suggested in order to achieve a complete bacterial eradication prior to peri-apical surgery. Approximately $95 \%$ of all peri-apical endodontic tooth therapies are efficacious and endodontic therapy may be elected for a non vital periapical granuloma or a cyst. A consecutive apicoectomy is indicated for lesions with an insidious recovery. The root canal, when administered to through the apical foramina, may elucidate an interim acute inflammation, epithelial ulceration or epithelial eradication or sub epithelial haemorrhage, thus aiding the evolution of the cyst into a granuloma which may disintegrate without further intervention. The external cortical plate is the initial site of healing if penetrated and metamorphosed and recovery may ensue within 2 months to a year.

\section{References}

1. Peters, E., Lau, M. Histopathology examination to confirm diagnosis of periapical lesions: a review. (2003) J Can Dent Assoc 69(9): 598-600.

Pubmed | Crossref $\mid$ Others

2. Gbolahan, O., Fatusi, O., Owotade, F., et al.Clinicopathology of soft tissue lesions of extracted teeth. (2008) J Oral Maxillofac Surg 66(11): 2284-2289.

Pubmed | Crossref | Others

3. Regezi, I.A. Oral Pathology; Clinical Pathologic Correlation(Ed 3). (1999) J oral maxillofac surg 58(4): 463.

Pubmed $\mid$ Crossref $\mid$ Others

4. Ledesma - Montes, C., Garcés - Ortíz, M., Rosales - García, G., et al. Importance of mast cells in human periapical lesions. (2004) J Endod 30(12): 855-859.

Pubmed | Crossref | Others

5. Liapatas, S., Nakou, M., Rontogianni, D. Inflammatory infiltrate of chronic periradicular lesions: An Immunohistochemical study. (2003) Int Endod J 36(7): 464 - 471.

Pubmed |Crossref $\mid$ others

6. Gasparoni, A., Regoli, M., Della, C. M., et al.Immunological and Ultra structural characterization of plasma cells in human periapical chronic inflammatory lesions (granulomas). (2005)Ital J Anat Embroyol 110 (1): 1-9.

Pubmed | Crossref| others

7. Neville, B.W.Oral Maxillofac Pathol $1^{\text {st }}$ Ed. (1995) Philadelphia, New York, WB Saunders \& Co: 703.

Pubmed $\mid$ Crossref $\mid$ Others

8. Kuc, I., Peters, E., Pan, J. Comparison of clinical \& histologic diagnosisin periapical lesion.(2000) Oral Surg Oral Med Oral Pathol
Oral Radiol Endod 89(3): 333-337.

Pubmed |Crossref | Others

9. Shafer, W.G., Barnet, M. Levy., Maynard, G. Text book of oral pathol $4^{\text {th }}$ Ed. (1983): 944.

Pubmed | Crossref $\mid$ Others

10. Stern, N.H., Dreizen, S., Mackler, B.F., et al.Quantitative Analysis of Cellular Composition of human periapical granuloma. (1981) J Endod 79(3): 117-122.

Pubmed | Crossref | Others

11. Atahanssiades, T.J., et al. Granuloma induction in peritoneal cavity. - A model for the study of inflammatory cytopoeisis in non lymphatic organs. (1972) J Reticulo endothelial Soc 11: 60-76. Pubmed | Crossref $\mid$ Others

12. Page, R.C., Davies, P., Allison, A. C. Pathogenesis of chronic inflammatory lesion induced by Group A streptococcal cell wall. (1974) Lab Invest 30(5): 568-581.

Pubmed |Crossref $\mid$ Others

13. Omoregie, F.O., Saheeb, B.D., Odukoya, O., et al. A clinic-pathologic correlation in the diagnosis of periradicular lesions of extracted teeth. (2009) J Oral \& Maxillofac Surg 67(7): 1387-1391. Pubmed |Crossref |Others

14. Anish, S., Prashanth, p., Kasim, k., et al.Periapical Granuloma. (2016) Int J of Prev and Clin Dent Research 3(1): 35-37.

Pubmed | Crossref $\mid$ Others

15. Omoregie, F.O., Ojo, M.A., Saheeb, B., et al. Periapical granuloma associated with extracted teeth. (2011)Niger J of Clin Pract 14(3): 293-296.

Pubmed | Crossref | Others

16. Image 1 Courtesy: Infoede ntis.com. (2012): 1.

Pubmed | Crossref $\mid$ Others

17. Image 2 Courtesy: Top coder.

Pubmed | Crossref $\mid$ Others

18. Image 3 Courtesy: Dentistry and Medicine.

Pubmed | Crossref $\mid$ Others

19. Image 4 Courtesy: Open I .com.

Pubmed | Crossref $\mid$ Others

20. Image 5 Courtesy: Flylib.com.

Pubmed | Crossref $\mid$ Others

21. Image 6 courtesy: Nature.com.

Pubmed | Crossref $\mid$ Others

Submit your manuscript to Ommega Publishers and we will help you at every step:

- We accept pre-submission inquiries

- Our selector tool helps you to find the most relevant journal

- We provide round the clock customer support

- Convenient online submission

- Thorough peer review

- Inclusion in all major indexing services

- Maximum visibility for your research

Submit your manuscript at

OMmega Publishers

https://www.ommegaonline.org/submit-manuscript 